\title{
Characterization of Winery Wastewater for Reuse in California
}

\author{
Maya C. Buelow, ${ }^{1}$ Kerri Steenwerth, ${ }^{2}$ Lucas C. R. Silva, ${ }^{1}$ \\ and Sanjai J. Parikh ${ }^{1 *}$
}

\begin{abstract}
More than thirty percent of the United States is currently in a drought that is expected to have profound social, economic, and environmental impacts. The intensification of drought conditions in southern and western regions of the country has spurred interest in wastewater reuse in agriculture, including in wine production. Presented here is the first data set of its kind to support California growers and vintners in the reuse of treated winery wastewater (WWW). The data provide a detailed description of California WWW, with particular emphasis on salinity, to enable the benefits and risks of land application to be assessed. Monthly samples were obtained over a 20-month period from 18 wineries in Ukiah, Napa, Lodi, King City, and Paso Robles. Samples collected before and after physicochemical and biological treatment were analyzed for $\mathrm{pH}$, electrical conductivity (EC), cation and anion concentrations, specific ultraviolet absorbance $\left(\mathrm{SUVA}_{254}\right)$, dissolved organic carbon (DOC), and biological oxygen demand $\left(\mathrm{BOD}_{5}\right)$. The $\mathrm{pH}$ of the WWW varied widely (from 3 to 12$)$. Organic parameters $\left(\mathrm{SUVA}_{254}, \mathrm{DOC}_{\text {, }}\right.$ and $\mathrm{BOD}_{5}$ ) showed that treatment effectively decreased organic carbon to levels that would not have negative effects on plant growth or soil. Cation concentrations $\left(\mathrm{Na}^{+}, \mathrm{K}^{+}, \mathrm{Ca}^{2+}, \mathrm{Mg}^{2+}\right)$ in WWW were not reduced by treatment. These baseline data confirm that dissolved salts pose a challenge to the reuse of WWW. However, total salinity of the WWW was moderate (mean EC of $1.0 \mathrm{dS} / \mathrm{m}$ ) and usually below risk thresholds for common winegrape rootstocks and soil salinity hazards. The conditions under which WWW could be recommended as a water management option in California are described.
\end{abstract}

Key words: sodium, potassium, salinity, drought, reuse, BOD, greywater

The United States agricultural industry is vulnerable to social, economic, and environmental impacts caused by intensifying changes in climate (NOAA 2013). Projected increases in demand for fresh water and more frequent incidences of drought are raising interest in finding alternative sources of water (IPCC 2013). For the fast-growing and dynamic California wine industry, water reuse has emerged as an important management alternative. Local legislation has placed strict limits on agricultural water use, and regulations to meet habitat requirements for threatened wildlife have further reduced the availability of fresh water for irrigation. More stringent policies for maintaining in-stream flows in northern California (e.g., AB2121; North Coast Stream Flow Coalition 2009) have been in effect since 2009, and new landmark groundwater legislation, AB1739 (SWRCB 2014), SB 1168, and SB 1319 (CDFA 2014), was recently (September 2014) signed into law.

\footnotetext{
${ }^{1}$ Department of Land, Air and Water Resources, One Shields Ave., University of California Davis, Davis, CA 95616; and ${ }^{2}$ USDA/ARS Crops Pathology and Genetics Research Unit, c/o Department of Viticulture and Enology, RMI North, 595 Hilgard Ln., Davis, CA 95616.

*Corresponding author (sjparikh@ucdavis.edu; tel: 530-752-1265)

Acknowledgments: The authors thank the Kearney Foundation of Soil Science for funding this study and thank Xien Wang, Dr. Randall Dahlgren, Dr. Sandrine Matiasek, and Dr. Kim Mosse.

Supplemental data is freely available with the online version of this article at www.ajevonline.org.

Manuscript submitted Oct 2014, revised Mar 2015, accepted Apr 2015

Publication costs of this article defrayed in part by page fees.

Copyright (C) 2015 by the American Society for Enology and Viticulture. All rights reserved.

doi: 10.5344/ajev.2015.14110
}

These are among the key factors that have spurred interest in onsite reuse of winery wastewater (WWW).

Most WWW is generated from cooling and cleaning of the winery (Smyth and Russell 2009). WWW typically has widely variable acidity ( $\mathrm{pH} 3$ to 11 ) because of the addition of acidic grape juice and alkaline cleaners, and it contains dissolved sugars that alter biological oxygen demand $\left(\mathrm{BOD}_{5}\right)$ and dissolved organic carbon (DOC). The electrical conductivity (EC) of WWW typically ranges from 0.8 to $3.1 \mathrm{dS} / \mathrm{m}$ (Bustamante et al. 2005). Nitrogen (N) is also sometimes present (0 to $142 \mathrm{mg} / \mathrm{L}$ ), and phosphorus (P) concentrations are generally in the range of 3 to $188 \mathrm{mg} / \mathrm{L}$ (Bustamante et al. 2005). WWW is rich in potassium $\left(\mathrm{K}^{+}\right)$and sodium $\left(\mathrm{Na}^{+}\right)$ salts because of naturally occurring $\mathrm{K}^{+}$in grapes and $\mathrm{K}^{+}$and $\mathrm{Na}^{+}$introduced in cleaning agents. When applied via irrigation, dissolved $\mathrm{K}^{+}$and $\mathrm{Na}^{+}$can negatively affect soil chemistry and physical structure and can reduce hydraulic conductivity (HC; Ayers and Westcot 1985). Although $\mathrm{K}^{+}$may be less detrimental to soil structure than $\mathrm{Na}^{+}$because of its smaller hydrated radius, there is no consensus on the impact of increasingly $\mathrm{K}^{+}$-rich waters on soils and plant health (Boulton 1980, Morlat 2008).

Problems associated with $\mathrm{Na}^{+}$accumulation in soils are well recognized, and longstanding agricultural guidelines define the conditions that induce swelling, dispersion, and subsequent infiltration (Ayers and Westcot 1985). A variety of physicochemical and biological treatment methods are used to produce wastewater effluent that is suitable for irrigation of crops, including grapevines (Hamilton et al. 2007). Physicochemical methods rely on evaporation in ponds and often use sprinklers or aerators to increase evaporation; flocculating agents 
and filtration systems are also used (Hamilton et al. 2007, Mosse et al. 2011). Biological methods use immobilized or suspended microorganisms in anaerobic digestion and aerobic treatment (Laurenson et al. 2012, Oliver et al. 2008).

Management requirements for WWW are unique because the composition and volume of the effluent stream is seasonally variable, with the majority of the wastewater produced during vintage, which usually falls between September and November in the northern hemisphere (Laurenson et al. 2012, Mosse et al. 2013b). WWW is most often treated onsite and provides a large potential alternative water source for irrigation and landscaping. Adjustment of $\mathrm{pH}$ and screening of gross solids is required prior to discharge of WWW to a municipal system. WWW can also be discharged to a leach field, and small wineries can use septic tanks (Malandra et al. 2003). Most wineries that produce more than 40,000 cases per year treat their wastewater on site; aerated ponds are the simplest, most common, and least expensive treatment method (Storm 2001). The ponds are treated as fermentation systems and require appropriate temperature, nutrients, and $\mathrm{pH}$ to remove organics (mostly dissolved sugars). Clarifiers are used after pond treatment to remove settleable solids, and the settled sludge can be returned to the ponds to maintain an active inoculum (Storm 2001). Aerated ponds usually succeed at reducing $\mathrm{BOD}_{5}$ and total solids (Arienzo et al. 2009, Laurenson et al. 2012). In addition, wetland systems used for tertiary treatment can remove most ( $\sim 98 \%$ ) organic content from WWW, but the large initial investment and land required for wetland construction can be deterrents to their use (Shepherd et al. 2001). Anaerobic ponds and digesters are not commonly used for WWW treatment because of the highly variable flow rates of the waste stream and concerns about the odors often associated with anaerobic processes (Mosse et al. 2011).

None of these treatment options has been shown to remove salts (Christen et al. 2010). A review of the efficacy of various treatment approaches describes electrodialysis, ion exchange, and reverse osmosis as possible physiochemi- cal methods for salt removal, but the disadvantages of these systems include requirements for specialized equipment and operator expertise, high cost, and large energy inputs (Mosse et al. 2011). Previous studies have investigated the characteristics of WWW (Bustamante et al. 2005, Conradie et al. 2014, Eales et al. 2014, Hamilton et al. 2007, Mosse et al. 2013b). The objectives of this study were to evaluate the effectiveness of existing onsite WWW treatment options and to assess the challenge of salinity for WWW reuse in California. This survey is the first of its kind in the state and examines WWW across a spectrum of production volumes and treatment options, considering application thresholds of common winegrape rootstocks and soil salinity hazards.

\section{Materials and Methods}

Sample collection and background survey. Eighteen California wineries were selected for this study based on site visits in July 2010. Background surveys covering general information about wine production and winery cleaning practices were conducted to ensure that the participating wineries represented diverse annual crush, production, and effluent volumes, percent red and white wine produced, cleaners used, and WWW treatment and reuse approaches. The types of cleaners used by each winery were also tabulated (Supplemental Table 1). Represented treatment methods included physicochemical (sumps, leach fields, and evaporation ponds) and biological methods (aerated ponds, bioreactors, wetlands, and trickle towers). The wineries recorded their activities at the time of sampling (e.g., floor or barrel washing, crush, harvest, racking, lees filtering, sanitation, wine spillage, bottling, and rain; Table 1).

Winery employees collected monthly pre- and posttreatment WWW samples for 20 months (from November 2010 to June 2012). Duplicate 250-mL polypropylene bottles (SKS Science, Watervliet, NY) were rinsed three times with sample water, filled to the lip, and sealed. Samples were shipped overnight on ice to the University of California, Davis. Upon

Table 1 Percentage of wineries in which a given activity occurred at the time of sampling. Harvest and crush activities occur into December in California. The month sum total does not include rain, and values in bold indicate the six months with the highest activity. Barrel washing, racking, and sanitation were the most frequent activities. California vintage occurs from September to December; the off-season is January to August.

\begin{tabular}{|c|c|c|c|c|c|c|c|c|c|c|c|}
\hline Month & $\begin{array}{c}\text { Floor } \\
\text { washing }\end{array}$ & $\begin{array}{c}\text { Barrel } \\
\text { washing }\end{array}$ & Crush & Harvest & Racking & $\begin{array}{c}\text { Lees } \\
\text { filtering }\end{array}$ & Rain & Sanitation & Spills & Bottling & $\begin{array}{c}\text { Monthly } \\
\text { sum total }\end{array}$ \\
\hline Sept & 74 & 55 & 40 & 40 & 44 & 14 & 0 & 70 & 22 & 37 & 396 \\
\hline Oct & 37 & 75 & 87 & 62 & 87 & 75 & 12 & 87 & 25 & 12 & 547 \\
\hline Nov & 40 & 40 & 100 & 100 & 60 & 60 & 70 & 90 & 60 & 10 & 560 \\
\hline Dec & 83 & 91 & 41 & 41 & 100 & 50 & 75 & 91 & 66 & 33 & 596 \\
\hline Jan & 62 & 87 & 0 & 0 & 70 & 33 & 50 & 70 & 37 & 16 & 375 \\
\hline Feb & 0 & 0 & 0 & 0 & 33 & 33 & 33 & 33 & 33 & 0 & 132 \\
\hline March & 42 & 71 & 0 & 0 & 57 & 0 & 71 & 57 & 28 & 14 & 269 \\
\hline April & 66 & 86 & 0 & 0 & 86 & 20 & 66 & 66 & 13 & 53 & 390 \\
\hline May & 55 & 55 & 0 & 0 & 45 & 10 & 45 & 45 & 20 & 30 & 260 \\
\hline June & 53 & 86 & 0 & 0 & 46 & 6 & 46 & 73 & 20 & 33 & 317 \\
\hline July & 44 & 77 & 0 & 0 & 72 & 16 & 33 & 44 & 11 & 55 & 319 \\
\hline Aug & 44 & 66 & 0 & 0 & 33 & 11 & 11 & 50 & 22 & 61 & 287 \\
\hline Sum & 600 & 789 & 268 & 243 & 733 & 328 & 512 & 776 & 357 & 354 & \\
\hline
\end{tabular}


receipt, samples were prepared for analysis of chemical (cation and anion concentrations, $\mathrm{EC}, \mathrm{pH}$ ) and organic characteristics (DOC, $\left.\mathrm{BOD}_{5}, \mathrm{SUVA}_{254}\right)$.

Measurement of wastewater parameters. Immediately upon arrival at the laboratory, $\mathrm{pH}$ (Accumet Gel-filled PencilThin $\mathrm{pH}$ Combination Electrodes-Mercury-Free 13-620-290, Method 150.1; Fisher Scientific, Waltham, MA), EC (Orion 013005MD conductivity cell, Method 120.1; Fisher Scientific), and $\mathrm{BOD}_{5}$ (Orion 9708 Dissolved Oxygen probe; Thermo Scientific, Waltham, MA) of unfiltered samples were measured using an Orion 4-Star meter (Thermo Scientific) (Burt and Staff 2014). $\mathrm{BOD}_{5}$ was measured according to EPA method 5210 B (U.S. EPA 1979). Samples were filtered through a 0.45- $\mu \mathrm{m}$ Whatman (Little Chalfont, Buckinghamshire, England) glass fiber filter, and the filtrates were stored in two 50$\mathrm{mL}$ Falcon tubes (Corning Life Sciences, Tewksbury, MA). One tube was acidified using $1 \mu \mathrm{L} \mathrm{HCl}(12 \mathrm{~mol} / \mathrm{L})$ per $1 \mathrm{~mL}$ sample for DOC analysis; the other tube was not acidified and was stored at $1.6^{\circ} \mathrm{C}$ for analysis of $\mathrm{SUVA}_{254}$ and nitrate $\left(\mathrm{NO}_{3}{ }^{-}\right)$. For DOC, samples were placed in combusted 20$\mathrm{mL}$ glass DOC vials (National Scientific, Rockwood, TN) for analysis with a high-temperature catalytic oxidation analyzer (Shimadzu TOC-V, Kyoto, Japan). The mean of three to five $100-\mu \mathrm{L}$ injections was reported for each sample (Qian and Mopper 1996, Spencer et al. 2008). $\mathrm{NO}_{3}{ }^{-}$was measured by colorimetry (Doane and Horwath 2003). One $\mathrm{mL}^{-} \mathrm{NO}_{3}{ }^{-}$ reagent was transferred into a 1-mL microcuvette (BrandTech Scientific, Essex, CT), and $0.05 \mathrm{~mL}$ sample was added. After 8 to $12 \mathrm{hr}$ color development, absorbance at $\lambda=540 \mathrm{~nm}$ was measured with a Genesys $10 \mathrm{~S} U$ V-vis spectrophotometer (Thermo Scientific). For $\mathrm{SUVA}_{254}$, absorbance $(\lambda=254 \mathrm{~nm})$ was measured at room temperature with the Genesys $10 \mathrm{~S}$, and $\mathrm{SUVA}_{254}$ was determined by dividing the measured UV absorbance measured at $\lambda=254 \mathrm{~nm}$ by measured DOC (Spencer et al. 2008).

Concentrations of cations $\left(\mathrm{Na}^{+}, \mathrm{K}^{+}, \mathrm{NH}_{4}^{+}, \mathrm{Mg}^{2+}, \mathrm{Na}^{2+}\right)$ and anions $\left(\mathrm{Cl}^{-}, \mathrm{SO}_{4}{ }^{-}, \mathrm{Br}^{-}, \mathrm{NO}_{3}{ }^{-} \mathrm{PO}_{4}{ }^{3-}\right)$ were measured using a Dionex ICS-2000 ion chromatograph (Dionex, Sunnyvale, CA). Samples were prepared in duplicate and run according to ASTM cation determination method D6919-09 and EPA anion determination method 4110 (ASTM 2009, APHA 1992). The data were used to calculate the following metrics of WWW quality (concentrations in $\mathrm{mEq} / \mathrm{L}$ ): sodium adsorption ratio (SAR), potassium adsorption ratio (PAR), monovalent cation ratio (MCAR), and cation ratio of structural stability (CROSS) (Jayawardane et al. 2011) (Equations 1-4).

$$
\begin{array}{rlrl}
\mathrm{SAR} & =\mathrm{Na}^{+} /\left[\left(\mathrm{Ca}^{2+}+\mathrm{Mg}^{2+}\right) / 2\right]^{1 / 2} & & \text { Eq. } 1 \\
\mathrm{PAR} & =\mathrm{K}^{+} /\left[\left(\mathrm{Ca}^{2+}+\mathrm{Mg}^{2+}\right) / 2\right]^{1 / 2} & \text { Eq. } 2 \\
\text { MCAR } & =\left(\mathrm{Na}^{+}+\mathrm{K}^{+}\right) /\left[\left(\mathrm{Ca}^{2+}+\mathrm{Mg}^{2+}\right) / 2\right]^{1 / 2} & \text { Eq. } 3 \\
\text { CROSS } & =\left(\mathrm{Na}^{+}+0.56 \mathrm{~K}^{+}\right) /\left[\left(\mathrm{Ca}^{2+}+0.6 \mathrm{Mg}^{2+}\right) / 2\right]^{1 / 2} & & \text { Eq. } 4
\end{array}
$$

SAR is a weighted ratio of $\mathrm{Na}^{+}$to other cations in solution, and PAR is calculated similarly. The MCAR considers the combined effect of all cations in the solution, including $\mathrm{Na}^{+}$and $\mathrm{K}^{+}$(Jayawardane et al. 2011). CROSS considers the relative flocculating effects of magnesium $\left(\mathrm{Mg}^{2+}\right)$ and calcium
$\left(\mathrm{Ca}^{2+}\right)$ and the dispersive effects of $\mathrm{K}^{+}$and $\mathrm{Na}^{+}$(Rengasamy 2002). The relative flocculating powers as determined by Rengasamy (2002) are $\mathrm{Na}^{+}=1$; thus, the values are: $\mathrm{Na}^{+}=1, \mathrm{~K}^{+}$ $=1.8, \mathrm{Mg}^{2+}=27$, and $\mathrm{Ca}^{2+}=45$, and the equation uses these coefficients to estimate the reduction in $\mathrm{HC}$ for a given cation ratio. The CROSS equation can provide a more accurate prediction of the risk of saline water to soil HC (Jayawardane et al. 2011, Laurenson et al. 2012).

Data analysis. Statistical analyses were performed using JMP 10 (SAS Institute, Inc., Cary, NC). To meet assumptions of normality and homogeneity of variance, the data were logtransformed $\left(\log _{10}[x+1]\right)$ prior to analysis (Shapiro-Wilk test, $\mathrm{W} \geq 0.95$ ). Analysis of variance (ANOVA) was run using a mixed-effects model to test the significance $(p \leq 0.05)$ of fixed (year, month, water treatment) and random (site) effects and their interaction. There were no significant differences between sampling years for most variables, so data for the two years were combined to generate monthly averages, and mixed-effects ANOVA was used to test the significance $(p \leq$ 0.05 ) of fixed and random effects and their interaction. The effect of month and treatment on each parameter was reported (Table 2), and when interactions were significant, data were presented as pre- and posttreatment averages $\left(\mathrm{pH} / \mathrm{BOD}_{5} / \mathrm{DOC} /\right.$ $\mathrm{SUVA}_{254}$ ). Two-way ANOVA (main effect $=$ month, random effect $=$ site) was then used to examine temporal variation of all parameters on averages that removed any confounding interactive effects. When appropriate, Tukey's honestly significant difference (HSD) test was used to determine differences in mean values across months. For variables that did

\begin{tabular}{lccc}
\hline $\begin{array}{c}\text { Table } 2 ~ P \text {-values for analysis of variance (ANOVA), } \\
\text { differences }(p \leq 0.05) \text { for the whole model mean by month, }\end{array}$ \\
\multicolumn{4}{c}{ treatment, and interactions. All data except for pH are log } \\
transformed. nd = no data. $\mathrm{N}=579$.
\end{tabular}

aBiological oxygen demand; bdissolved organic carbon; ${ }^{\mathrm{c}}$ specific ultraviolet absorption; delectrical conductivity; ${ }^{\text {esodium adsorption }}$

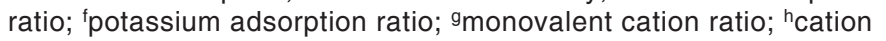
ratio of structural stability. 
not meet assumptions of normality or homogeneity of variance $\left(\mathrm{SUVA}_{254} / \mathrm{Br}^{-} / \mathrm{NO}_{3}{ }^{-} / \mathrm{NH}_{4}{ }^{+}\right.$), an equivalent non-parametric multiple comparison test (Steel-Dwass All Pairs) was used.

\section{Results and Discussion}

This survey reflects a wide range of management practices and treatments used by California wineries to improve WWW quality. Significant differences in WWW chemistry between months can be explained by different levels of winery activity during the year (e.g., vintage between September and December). No significant differences were observed between the two years of sampling. Consistent improvement in WWW quality was observed in all cases as a result of treatment, despite the temporal variation in WWW chemistry (Supplemental Figures 1-8), indicating effective management of variable loads and $\mathrm{BOD}_{5}$. This data set and previous research demonstrate that treated WWW could be reused for irrigation (Mosse et al. 2013a, Weber et al. 2014). A synthesis of the background survey and baseline values for each measured parameter is presented below.

Winery wastewater background survey. The data collected on monthly winery activity show that harvest and crush occurred only between September and December (Table 1). The three activities that were cited most often as contributing to WWW were barrel washing, sanitation, and racking (Table 1). Larger quantities of WWW were generated between September and December (vintage), but floor and barrel washing, racking, sanitation, and bottling occur (and thus produce $\mathrm{WWW}$ ) year-round. Differences between the time at which WWW is generated and the time when additional water is needed should be considered for a sustainable water management plan. The types of cleaners used by the wineries are summarized in Supplemental Table 1 and should also be considered when implementing best management strategies. Parameters that could be used to determine the safety of WWW reuse and associated baselines for future studies are described below.

Organics in winery wastewater. Changes in $\mathrm{BOD}_{5}$, DOC, and $\mathrm{SUVA}_{254}$, indicated that the organic content fluctuated according to month and WWW treatment (Table 2). Untreated WWW samples often had high $\mathrm{BOD}_{5}(>15,000$ $\mathrm{mg} / \mathrm{L})$, but all treatment methods typically reduced $\mathrm{BOD}_{5}$ to less than $150 \mathrm{mg} / \mathrm{L}$ (Figure 1). DOC showed the same trends as $\mathrm{BOD}_{5}$ (Supplemental Figure 1). The efficacy of WWW treatment was reflected by decreases in labile organic carbon $\left(\mathrm{BOD}_{5}\right.$ and DOC) from pre- to posttreatment (Tables 3-5).

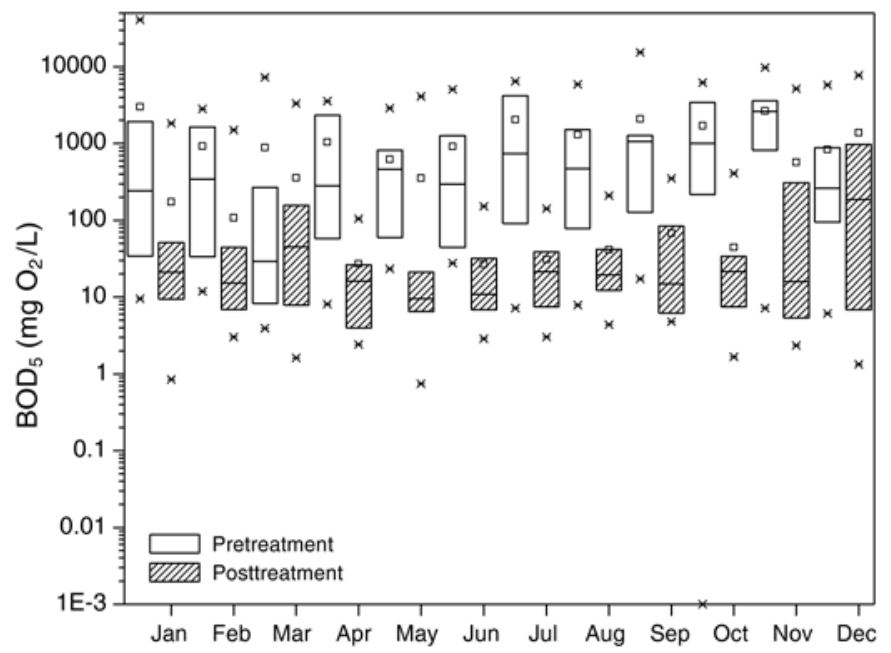

Figure 1 Biological oxygen demand $\left(\mathrm{BOD}_{5}\right)$ of all pre- and posttreatment samples (log scale). The 1st and 99th percentiles $(x)$ and mean values ( $\square$ ) are shown ( $n=36$ for Oct-March; $n=18$ for April-Sept).

\begin{tabular}{|c|c|c|c|c|c|}
\hline \multicolumn{3}{|c|}{ Off season pretreatment $(n=179)$} & \multicolumn{3}{|c|}{ Off season posttreatment $(n=142)$} \\
\hline 670 & 0.739 & $1.06 \times 10^{4}$ & 77.2 & 1.46 & $1.34 \times 10^{3}$ \\
\hline 1.47 & 0.00 & 83.2 & 0.57 & 0 & 4.28 \\
\hline 7.12 & 3.59 & 11.3 & 8.01 & 4.38 & 11.0 \\
\hline 0.97 & 0.137 & 3.26 & 0.88 & 0.198 & 2.4 \\
\hline 109 & 0.00 & $1.29 \times 10^{3}$ & 45.0 & 0.00 & 592 \\
\hline 4.22 & 0.00 & 95.3 & 3.39 & 0.00 & 209 \\
\hline 0.48 & 0.00 & 6.4 & 1.15 & 0.00 & 23.1 \\
\hline 17.1 & 0.00 & 237 & 12.5 & 0.00 & 209 \\
\hline 86.6 & 5.40 & 714 & 65.9 & 9.93 & 409 \\
\hline 133 & 1.31 & 1270 & 115 & 1.16 & 888 \\
\hline 1.36 & 0.146 & 27.65 & 1.09 & 0.22 & 6.9 \\
\hline 2.85 & 0.100 & 27.6 & 2.24 & 0.32 & 12.3 \\
\hline 2.43 & 0.100 & 16.0 & 1.93 & 0.32 & 10.2 \\
\hline
\end{tabular}

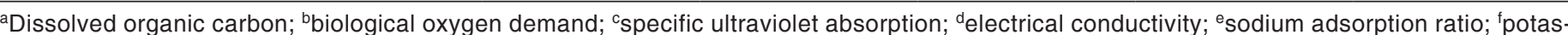
sium adsorption ratio; ${ }^{9}$ monovalent cation ratio; ${ }^{h}$ cation ratio of structural stability. 
The U.S. EPA $\mathrm{BOD}_{5}$ limit for a normal secondary treatment facility is $30 \mathrm{mg} / \mathrm{L}$ dissolved oxygen (monthly average), but most wineries are not classified as normal secondary treatment facilities and their permitted $\mathrm{BOD}_{5}$ limit may be $>65$ $\mathrm{mg} / \mathrm{L}$ (U.S. EPA 2004). However, $30 \mathrm{mg} / \mathrm{L} \mathrm{BOD}_{5}$ is the EPA's recommended maximum for any water source intended for reuse; if the intended use for treated WWW is irrigation of a valuable cash crop such as grapes, it would behoove the grower to meet this limit.

The effects of month on $\mathrm{pH}, \mathrm{BOD}_{5}$, DOC, and $\mathrm{SUVA}_{254}$ were examined separately from treatment because of significant interactions (Table 2). Pretreatment $\mathrm{BOD}_{5}$ values were highest between October and February (Figure 1), when crush and harvest activities including sanitation, spills, lees filtering, barrel and floor washing, and racking were all major contributors to WWW (Table 1; Conradie et al. 2014). The high $\mathrm{BOD}_{5}$ in pretreatment WWW in April was likely a result of racking and bottling; high values in July could be attributed to preparation for harvest and crush (Figure 1; Conradie et al. 2014).

Posttreatment $\mathrm{BOD}_{5}$ increased to almost $100 \mathrm{mg} / \mathrm{L}$ in November and December, a time of high activity for California wineries, showing that treatment was less effective during this period (Figure 1). The WWW generated during these months is stored and mixed with WWW from other times of the year and sometimes with freshwater sources (Waisdorff et al. 2005). This practice may contribute to the reduction in posttreatment $\mathrm{BOD}_{5}$ (Figure 1) to $\sim 10 \mathrm{mg} / \mathrm{L}$ by early spring (March to April), and during summer (June to August). The differences in $\mathrm{BOD}_{5}$ concentrations throughout the year confirm the high temporal variability of WWW streams. It is critical to consider the variability in organic and inorganic characteristics and volume of WWW at different times of year when developing a sustainable water management plan. These considerations will be unique to each winery, but treatment and storage of WWW will generally be necessary to provide water suitable for land application at critical times of the year.

SUVA $_{254}$ is the mean absorptivity of the molecules constituting the DOC in water samples and is an indicator of the aromatic fraction of DOC and a proxy for phenol and tannin concentrations, the more recalcitrant constituents of WWW (Mosse et al. 2013b, Weishaar et al. 2003). The mean annual SUVA 254 value in this study was $0.64 \mathrm{~L} / \mathrm{mg}-\mathrm{m}$; $\mathrm{SUVA}_{254}$ values in this range indicate that about $\leq 10 \%$ of the DOC is aromatic (Weishaar et al. 2003). An increase in $\mathrm{SUVA}_{254}$ to almost $6 \mathrm{~L} / \mathrm{mg}-\mathrm{m}$ in January (after the vintage) suggested that there was a large fraction of recalcitrant carbon in the WWW stream (Figure 2). Overall, posttreatment $\mathrm{SUVA}_{254}, \mathrm{BOD}_{5}$, and DOC of treated WWW were below maximum thresholds for concentrations that would be harmful to soil and plants (Tables 3 and 4; Laurenson et al. 2012, Weber et al. 2014).

\begin{tabular}{ccc}
\hline Table 5 & $P$-values for analysis of variance (ANOVA) of pre- \\
and posttreatment data with main effect of month where \\
interactions between month and treatment were observed. \\
All data except for $\mathrm{pH}$ are log transformed. \\
Asterisks indicate significant results. $\mathrm{N}=579$. \\
\hline \multicolumn{4}{c}{ Month pretreatment } & Month posttreatment \\
\hline $\mathrm{pH}$ & 0.0876 & $0.0003^{*}$ \\
$\mathrm{BOD}_{5}{ }^{\mathrm{a}}$ & $<0.0001^{*}$ & $0.0003^{*}$ \\
$\mathrm{DOC}^{\mathrm{b}}$ & $0.0001^{*}$ & 0.2107 \\
SUVA $^{\mathrm{c}}$ & $<0.0001^{*}$ & $<0.0001^{*}$
\end{tabular}

aBiological oxygen demand; ${ }^{b}$ dissolved organic carbon; 'specific ultraviolet absorption.

Table 4 Organic and chemical characteristics of winery wastewater, pre- and posttreatment, during the California vintage (September-December).

\begin{tabular}{|c|c|c|c|c|c|c|}
\hline & \multicolumn{3}{|c|}{ Vintage pretreatment $(n=146)$} & \multicolumn{3}{|c|}{ Vintage posttreatment $(n=112)$} \\
\hline & Mean & Min & Max & Mean & Min & Max \\
\hline $\mathrm{DOC}^{\mathrm{a}}(\mathrm{mg} / \mathrm{L})$ & 808 & 1.63 & $9.14 \times 10^{3}$ & 129 & 2.53 & $1.73 \times 10^{3}$ \\
\hline $\mathrm{BOD}_{5}{ }^{\mathrm{b}}(\mathrm{mg} / \mathrm{L})$ & $1.79 \times 10^{3}$ & 6.09 & $1.54 \times 10^{4}$ & 577 & 1.33 & $7.76 \times 10^{3}$ \\
\hline $\operatorname{SUVA}^{c}(\mathrm{~L} / \mathrm{mg}-\mathrm{m})$ & 0.15 & 0.00 & 2.44 & 0.37 & 0.000 & 3.08 \\
\hline $\mathrm{pH}$ & 6.92 & 3.58 & 12.9 & 7.80 & 4.58 & 9.64 \\
\hline $\mathrm{EC}^{\mathrm{d}}(\mathrm{dS} / \mathrm{m})$ & 1.32 & 0.37 & 9.70 & 1.17 & 0.32 & 4.66 \\
\hline $\mathrm{Cl}^{-}(\mathrm{mg} / \mathrm{L})$ & 48.8 & 2.28 & $1.05 \times 10^{3}$ & 44.0 & 5.77 & 541 \\
\hline $\mathrm{SO}_{4}^{2-}(\mathrm{mg} / \mathrm{L})$ & 99.7 & 0.00 & $1.08 \times 10^{3}$ & 58.7 & 1.73 & 374 \\
\hline $\mathrm{Br}^{-}(\mathrm{mg} / \mathrm{L})$ & 1.59 & 0.00 & 15.0 & 1.26 & 0.00 & 10.2 \\
\hline $\mathrm{NO}_{3}^{-}(\mathrm{mg} / \mathrm{L})$ & 3.03 & 0.00 & 15.8 & 5.04 & 0.00 & 48.8 \\
\hline $\mathrm{PO}_{4}{ }^{3-}(\mathrm{mg} / \mathrm{L})$ & 17.0 & 0.00 & 100 & 17.5 & 0.00 & 67.7 \\
\hline $\mathrm{Na}^{+}(\mathrm{mg} / \mathrm{L})$ & 137 & 6.84 & $3.06 \times 10^{3}$ & 99.5 & 12.5 & 351 \\
\hline $\mathrm{K}^{+}(\mathrm{mg} / \mathrm{L})$ & 176 & 3.18 & 772 & 162 & 1.91 & 568 \\
\hline $\mathrm{Mg}^{2+}(\mathrm{mg} / \mathrm{L})$ & 31.2 & 2.52 & 219 & 60.5 & 6.38 & 746 \\
\hline $\mathrm{Ca}^{2+}(\mathrm{mg} / \mathrm{L})$ & 75.5 & 7.84 & 356 & 79.5 & 21.4 & 268 \\
\hline $\operatorname{SAR}^{\mathrm{e}}(\mathrm{mEq} / \mathrm{L})$ & 2.43 & 0.21 & 46.9 & 1.66 & 0.21 & 5.26 \\
\hline $\mathrm{PAR}^{f}(\mathrm{mEq} / \mathrm{L})$ & 1.87 & 0.04 & 11.8 & 1.48 & 0.028 & 6.61 \\
\hline $\operatorname{MCAR}^{g}(\mathrm{mEq} / \mathrm{L})$ & 4.21 & 0.28 & 52.5 & 3.12 & 0.31 & 9.41 \\
\hline CROSS $^{\text {h }}(\mathrm{mEq} / \mathrm{L})$ & 3.65 & 0.20 & 51.9 & 2.68 & 0.31 & 8.19 \\
\hline
\end{tabular}

${ }^{a}$ Dissolved organic carbon; biological oxygen demand; ' ${ }^{\text {specific }}$ ultraviolet absorption; ${ }^{d}$ electrical conductivity; ${ }^{e}$ sodium adsorption ratio; ${ }^{f}$ potassium adsorption ratio; ${ }^{9}$ monovalent cation ratio; ${ }^{\mathrm{h}}$ cation ratio of structural stability. 
Acidity of winery wastewater. The $\mathrm{pH}$ of WWW differed by month (Supplemental Table 2) and increased after treatment. Posttreatment $\mathrm{pH}$ also differed seasonally, increasing up to harvest and crush (July and August; Table 2 and Supplemental Table 2). Cleaning agents used in the winery and chemical compounds used in winemaking affect the pH of WWW (Mosse et al. 2011, Sims and Morris 1984). The increase in posttreatment $\mathrm{pH}$ is in contrast to observations of low posttreatment $\mathrm{pH}$ in Spain and Greece (Bustamante et al. 2005, Vlyssides et al. 2005). High pH values can be attributed to the use of alkaline cleaning agents (i.e., sodium percarbonate $\left[2 \mathrm{Na}_{2} \mathrm{CO}_{3} \cdot 3 \mathrm{H}_{2} \mathrm{O}_{2}\right]$, sodium carbonate $\left[\mathrm{Na}_{2} \mathrm{CO}_{3}\right]$, and sodium and potassium hydroxide $[\mathrm{NaOH}, \mathrm{KOH}])$. The difference in mean $\mathrm{pH}$ of WWW from California wineries suggests that larger quantities of alkaline compounds were introduced by these wineries compared to other wine regions (Mosse et al. 2011). In this study, WWW samples were taken from both pre- and posttreatment sites. This may make comparison to other studies difficult because many studies do not specify where in the treatment stream WWW samples were taken; however, WWW is presumably sampled prior to treatment. Findings from various winemaking regions demonstrate that regional differences in practice influence the $\mathrm{pH}$ of WWW.

Chemical characteristics of winery wastewater. One of the biggest challenges to irrigation with treated WWW is to evaluate and mitigate the risk of salinity to plants and soil. Total $\mathrm{N}$ concentrations in WWW are usually low to moderate and can provide an additional source of $\mathrm{N}$ fertilizer. Grapevines remove only about $4 \mathrm{~kg} \mathrm{P} / \mathrm{ha} / \mathrm{yr}$ (Conradie and Saayman 1989), so total $\mathrm{P}$, which is generally between 3 and 188 $\mathrm{mg} / \mathrm{L}$, can be a concern. In this study, the mean posttreatment $\mathrm{PO}_{4}{ }^{-}$concentration was $13.5 \mathrm{mg} / \mathrm{L}$, which would allow for land application of up to $300,000 \mathrm{~L} / \mathrm{ha} \mathrm{WWW}$ while minimizing P runoff. Many treatment approaches (e.g., biofilters or chemical precipitation) can effectively reduce $\mathrm{P}$ concentrations (Leverenze 2002).

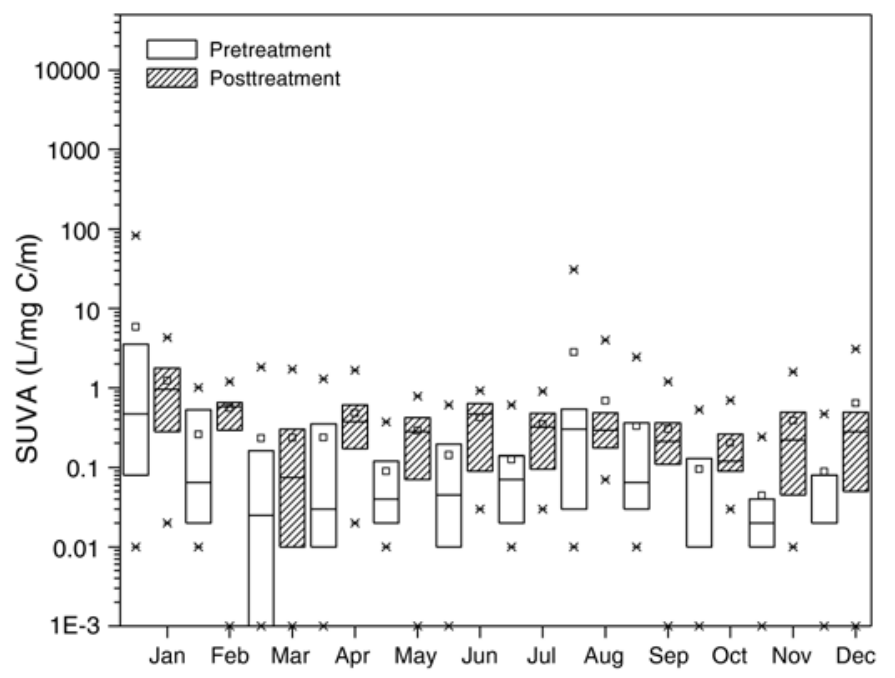

Figure 2 Specific ultraviolet absorption $\left(\mathrm{SUVA}_{254}\right.$ ) of all pre- and posttreatment samples (log scale). The 1st and 99th percentiles $(x)$ and mean values $(\square)$ are shown ( $n=36$ for Oct-March; $n=18$ for April-Sept).
The persistence of salts in solution can be seen by the similarity in pre- and posttreatment EC values and ion concentrations (Tables 3 and 4). The posttreatment EC of the WWW sampled for this study was usually $<2 \mathrm{dS} / \mathrm{m}$ and the maximum was $4.66 \mathrm{dS} / \mathrm{m}$. The pre- and post-treatment mean EC were both close to $1 \mathrm{dS} / \mathrm{m}$. Cation concentrations ranged from 1 to $3,100 \mathrm{mg} / \mathrm{L}$ and did not differ before and after treatment, but there were monthly differences in some compounds (Table 2). Concentrations of $\mathrm{Na}^{+}, \mathrm{Ca}^{2+}, \mathrm{Mg}^{2+}, \mathrm{Cl}^{-}, \mathrm{PO}_{4}^{3-}$, and $\mathrm{NO}_{3}{ }^{-}$ increased in November (Supplemental Figures 3-6, Supplemental Table 2), and unlike the individual ion concentrations in this study, SAR did not differ between months (Figure 3). This was due to concurrent increases in mono- and divalent ions that buffered the salinity risk presented by high $\mathrm{Na}^{+}$or $\mathrm{K}^{+}$concentrations and maintained mean SAR close to 2 and PAR close to 1.5 (Table 3). PAR increased in July and September (Figure 4). The MCAR and CROSS equations reflect

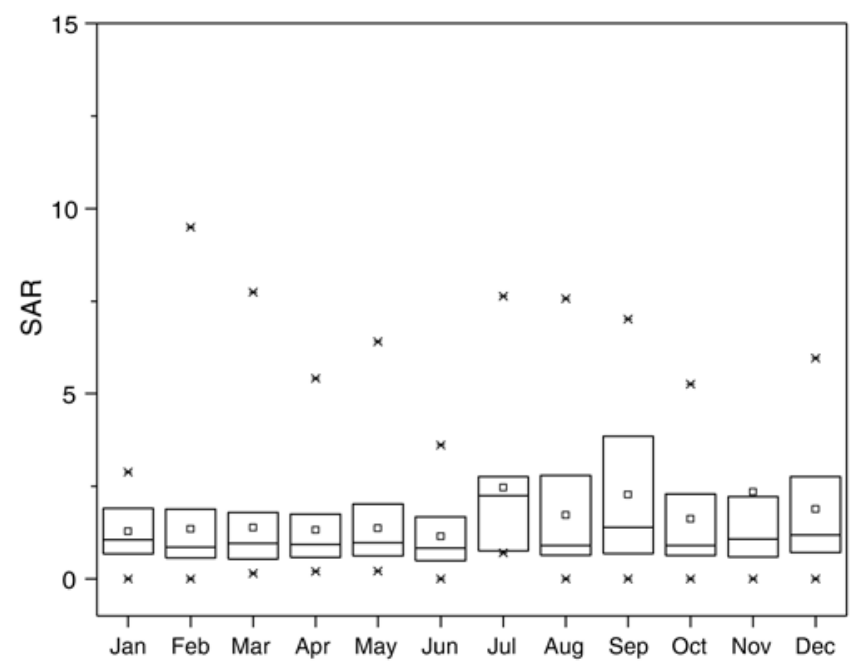

Figure 3 Posttreatment average monthly sodium absorption ratio (SAR). The 1st and 99th percentiles $(x)$ and mean values $(\square)$ are shown $(n=36$ for Oct-March; $\mathrm{n}=18$ for April-Sept).

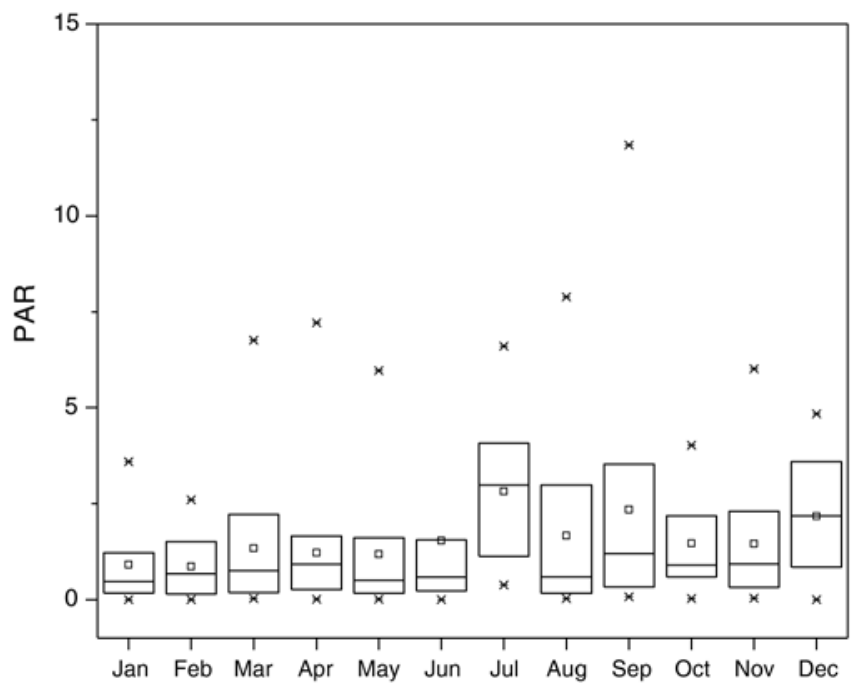

Figure 4 Posttreatment monthly potassium absorption ratio (PAR). The 1st and 99th percentiles $(x)$ and mean values $(\square)$ are shown $(n=36$ for Oct-March; $n=18$ for April-Sept). 
the contribution of each major cation to the total salinity of a solution. One study observed that MCAR and CROSS values from 6 to 52 could negatively affect soil HC (Jayawardane et al. 2011). The calculated MCAR (Eq. 3) and CROSS (Eq. 4) values were more synchronized than SAR or PAR with seasonal fluctuations in cation concentrations, increasing in September and November and decreasing in January through March (Supplemental Figures 7 and 8). The mean CROSS values of 2 to 5 throughout the year (Tables 3 and 4) indicated that cation ratios were not above the threshold value for reductions in soil HC.

Most anions were present at low concentrations. Chloride $\left(\mathrm{Cl}^{-}\right)$is of concern to growers because of its potential toxicity at high concentrations (Weber et al. 2014). $\mathrm{Cl}^{-}$concentrations observed here were usually moderate, ranging from 2 to 541 $\mathrm{mg} / \mathrm{L}$ posttreatment (Table 3), and increased in November (Supplemental Table 3B). Even the maximum posttreatment $\mathrm{Cl}^{-}$concentrations could only be harmful to the most saltsensitive grape rootstocks, namely Cardinal and Black Rose (Weber et al. 2014). Therefore, when reusing treated WWW in California, potential $\mathrm{Cl}^{-}$toxicity to grapevines can be avoided by monitoring and diluting the WWW as needed (Weber et al. 2014). Dissolved salts can also be removed by electrodialysis, ion exchange, and reverse osmosis, but these methods are not commonly used because of their expense and energy requirements (Mosse et al. 2011).

Despite the moderate total salt concentrations indicated by EC of WWW in this study, $\mathrm{Na}^{+}$and $\mathrm{K}^{+}$were sometimes present at concentrations that would be high enough to reduce soil HC via osmotic swelling (Figure 5). Sodium is a large monovalent ion and more effectively forces clay tactoids apart than $\mathrm{Ca}^{2+}$ or $\mathrm{Mg}^{2+}$ (Quirk 1986). Based on water infiltration risk zones for $\mathrm{Na}^{+}$established by Quirk and Schofield (1955) and revised by Ayers and Westcot (1985), SAR values from 3 to 9 pose a slight to moderate risk of reducing infiltration at EC $>0.3$ to $0.5 \mathrm{dS} / \mathrm{m}$ and are severely hazardous at $\mathrm{EC}<0.3$ to $0.5 \mathrm{dS} / \mathrm{m}$ (Ayers and Westcot 1985). Therefore, considering the $\mathrm{Na}^{+}$and $\mathrm{K}^{+}$concentrations seen in this study, the most common risk scenario for California wineries was for $\mathrm{Na}^{+}$ concentrations to exceed $3 \mathrm{dS} / \mathrm{m}$ while total $\mathrm{EC}$ remained below $1 \mathrm{dS} / \mathrm{m}$ (Figure 5). However, a recent seven year study of a Napa vineyard irrigated with recycled Napa Sanitation District water with SAR values slightly above the recommended limit of 3 showed that $\mathrm{Na}^{+}$accumulation could be managed with gypsum application and with no negative effects to soil, plants, or fruit (Weber et al. 2014). Figure 5 shows the risk zones superimposed onto the posttreatment SAR-EC data. Most data points fell into zones of no or moderate risk of reduced infiltration; points at severe risk of reduced $\mathrm{HC}$ had total $\mathrm{EC}$ values $<1 \mathrm{dS} / \mathrm{m}$. This risk is due to dispersion that occurs in dilute electrolyte solutions because of the electric double-layer phenomenon and is independent of $\mathrm{Na}^{+}$or $\mathrm{K}^{+}$ concentrations when EC $<0.2 \mathrm{dS} / \mathrm{m}$ (Ayers and Westcot 1985). Figure 6 depicts the calculated threshold electrolyte concentration (solid line) at different CROSS values; most samples were above the threshold, indicating that the WWW should not reduce soil HC.

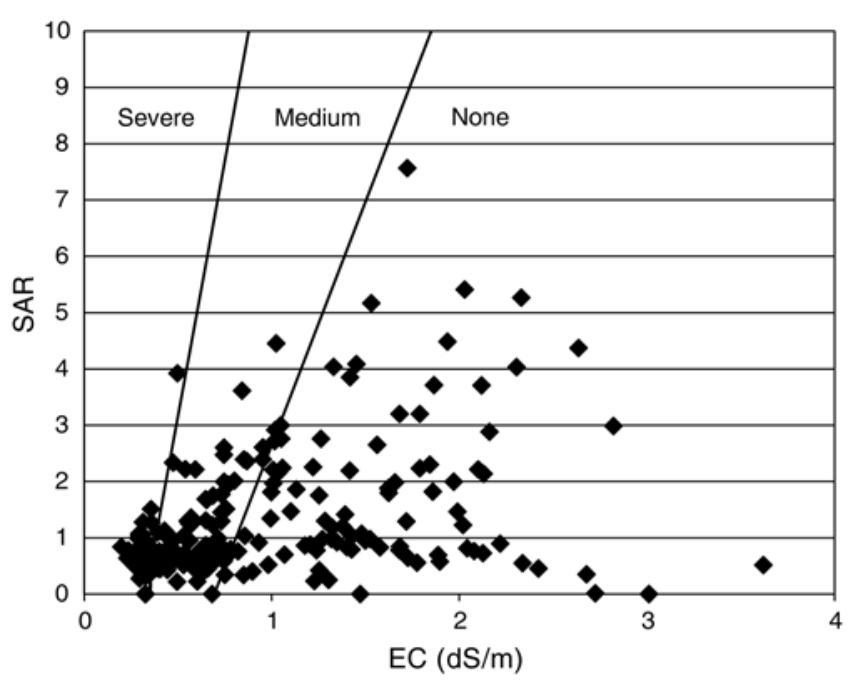

Figure 5 Posttreatment sodium absorption ratio (SAR) plotted by electrical conductivity (EC). Risk zones adapted from Ayers and Westcot (1985).

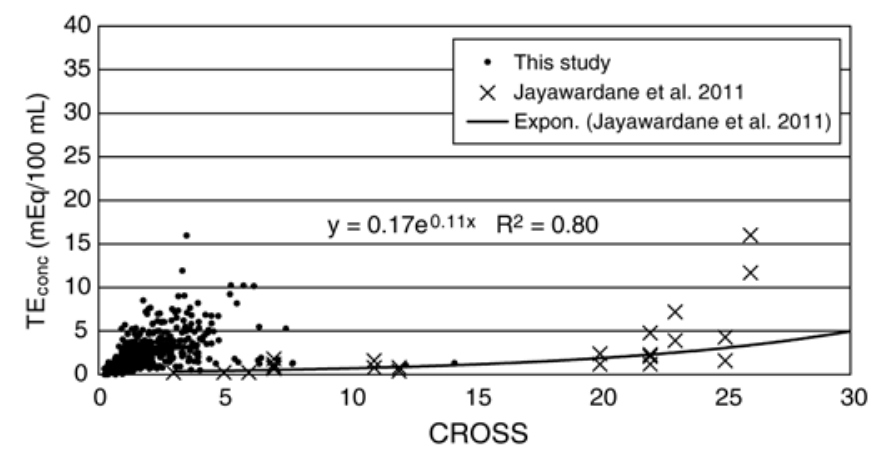

Figure 6 Measured electrolyte concentrations (EC, mEq/100 mL) plotted with an experimentally determined threshold electrolyte concentration ( $\mathrm{TE}_{\mathrm{conc}}$ ) curve established by Jayawardane et al. (2011), using the cation ratio of structural stability (CROSS) values for a smectitic soil.

Depending on soil mineralogy, the effects of salinity on soil $\mathrm{HC}$ can differ from the established risk zones (Buelow 2013). If the vineyard soil is predominantly montmorillonite or vermiculite, $\mathrm{HC}$ may be reduced less by elevated levels of $\mathrm{K}^{+}$compared to $\mathrm{Na}^{+}$. However, if the soil is dominated by kaolinite, increased $\mathrm{K}^{+}$concentrations could be at least as detrimental to soil $\mathrm{HC}$ as increases in $\mathrm{Na}^{+}$(Buelow 2013, Buelow et al. 2015). Therefore site-specific assessment of water and soil prior to reuse of treated WWW is recommended (Buelow 2013, Buelow et al. 2015, Frenkel 1985, Frenkel et al. 1978).

\section{Conclusion}

This survey is the first to characterize winery wastewater for wine regions in California. The data reflect seasonal variation in WWW and effects of common treatment approaches and will serve as a baseline. Findings from this and other published studies strongly suggest that WWW has great potential for onsite reuse. Concentrations of $\mathrm{BOD}_{5}$ and $\mathrm{DOC}$ are commonly monitored to ensure that soils are not overloaded with organic carbon, and both are effectively reduced by treatment. Although total P may also be of concern from a regulatory 
standpoint, it too can be effectively reduced by treatment. Elevated salt concentrations are difficult to remove and present the greatest challenge to reuse of WWW; however, the salinity of wastewater samples from the 18 participating wineries is mostly acceptable for irrigation, and the observed $\mathrm{Cl}^{-}$concentrations should not negatively impact vine growth. Furthermore, the time of year when higher salt concentrations were measured did not coincide with the season when treated WWW would be used as an additional water source in vineyards. This temporal offset allows for mixing of WWW streams and for mitigation of high salt concentrations. Despite measures to ensure that high concentrations of $\mathrm{Na}^{+}$and $\mathrm{K}^{+}$are not introduced into agricultural soils, their variable impact on soils of differing mineralogy highlights an area in need of further research. Data and risk-assessment tools that are currently available to winemakers and growers suggest that reuse of treated WWW is possible and should be pursued in California. However, regular monitoring and establishment of geographically specific guidelines are necessary for the widespread use of WWW for irrigation.

\section{Literature Cited}

APHA. 1992. Standard methods for the examination of water and wastewater, Method 4110, Determination of anions by ion chromatography. In 18th Edition of Standard Methods. American Water Works Association, Water Environment Federation. Alexandria, VA.

Arienzo, M., E.W. Christen, W. Quayle, and A. Kumar. 2009. A review of the fate of potassium in the soil-plant system after land application of wastewaters. J. Hazard Mater. 164:415-422.

ASTM. 2009. D6919-09, Standard test method for determination of dissolved alkali and alkaline earth cations and ammonium in water and wastewater by ion chromatography. ASTM International, West Conshohocken, PA.

Ayers, R.S.W., and D.W. Westcot. 1985. Water Quality for Agriculture. Food and Agriculture Organization of the United Nations, Rome.

Boulton, R. 1980. The general relationship between potassium, sodium and $\mathrm{pH}$ in grape juice and wine. Am. J. Enol. Vitic. 31:182-186.

Buelow, M.C. 2013. Properties of winery wastewater and the effects of treated wastewater applications on soil hydraulic conductivity. Thesis, University of California, Davis, CA.

Buelow, M.C., K. Steenwerth, and S.J. Parikh. 2015. The effect of mineral-ion interactions on soil hydraulic conductivity. Agr. Water Manage. 152:277-285.

Burt, R., and Soil Survey Staff. 2014. Soil survey investigations report no. 42, version 5.0. In Kellogg Soil Survey Laboratory Methods Manual. U.S. Department of Agriculture, Natural Resources Conservation Service, Lincoln, NE.

Bustamante, M.A., C. Paredes, R. Moral, J. Moreno-Caselles, A. Pérez-Espinosa, and M.D. Pérez-Murcia. 2005. Uses of winery and distillery effluents in agriculture: Characterisation of nutrient and hazardous components. Water Sci. Technol. 51:145-151.

CDFA. 2014. Ag leaders on-hand as Governor Brown signs landmark groundwater legislation. In Planting Seeds: Food and Farming News from CDFA. California Department of Food and Agriculture, Office of Public Affairs, Sacramento, CA. (cdfa.ca.gov)

Christen, E.W., W.C. Quayle, M.A. Marcoux, M. Arienzo, and N.S. Jayawardane. 2010. Winery wastewater treatment using the land filter technique. J. Environ. Manage. 91:1665-1673.

Conradie, A., G.O. Sigge, and T.E. Cloete. 2014. Influence of winemaking practices on the characteristics of winery wastewater and water usage of wineries. S. Afr. J. Enol. Vitic. 35:10-19.
Conradie, W.J., and D. Saayman. 1989. Effects of long-term nitrogen, phosphorus, and potassium fertilization on Chenin blanc vines. 1 . Nutrient demand and vine performance. Am. J. Enol. Vitic. 40:85-90.

Doane, T.A., and W.R. Horwath. 2003. Spectrophotometric determination of nitrate with a single reagent. Anal. Lett. 36:2713-2722.

Eales, K., M. Carson, J. Constable, A. Kumar, and P. Grbin. 2014. Winery wastewater project refreshes understanding of treatment processes: Can we help manage biological wastewater treatment systems better? Wine Vit. J. 29:36-37.

Frenkel, H., and A. Meiri. 1985. Soil Salinity: Two Decades of Research in Irrigated Agriculture. Van Nostrand Reinhold.

Frenkel, H., J.O. Goertzen, and J.D. Rhoades. 1978. Effects of clay type and content, exchangeable sodium percentage, and electrolyte concentration on clay dispersion and soil hydraulic conductivity. Soil Sci. Soc. Am. J. 42:32-39.

Hamilton, A.J., F. Stagnitti, X. Xiong, S.L. Kreidl, K.K. Benke, and P. Maher. 2007. Wastewater irrigation: The state of play. Vadose Zone J. 6:823-840.

IPCC. 2013. Summary for Policymakers. In Climate Change 2013: The Physical Science Basis. Contribution of Working Group I to the Fifth Assessment Report of the Intergovernmental Panel on Climate Change. T.F. Stocker et al. (eds.). Cambridge University Press, Cambridge, UK and New York, NY.

Jayawardane, N.S., E.W. Christen, M. Arienzo, and W.C. Quayle. 2011. Evaluation of the effects of cation combinations on soil hydraulic conductivity. Soil Res. 49:56-64.

Laurenson, S., N.S. Bolan, E. Smith, and M. McCarthy. 2012. Review: Use of recycled wastewater for irrigating grapevines. Aust. J. Grape Wine Res. 18:1-10.

Leverenze, H., G. Tchobanoglous, and J.L. Darby. 2002. Review of technologies for the onsite treatment of wastewater in California. Prepared for the California State Water Resources Control Board. H. Leverenze et al. (eds.), p. xix. Department of Civil and Environmental Engineering, Sacramento, CA, and University of California, Davis, CA.

Malandra, L., G. Wolfaardt, A. Zietsman, and M. Viljoen-Bloom. 2003. Microbiology of a biological contactor for winery wastewater treatment. Water Res. 37:4125-4134.

Morlat, R. 2008. Long-term additions of organic amendments in a Loire Valley vineyard on a calcareous sandy soil. II. Effects on root system, growth, grape yield, and foliar nutrient status of a Cabernet franc vine. Am. J. Enol. Vitic. 59:364-374.

Mosse, K.P.M., A.F. Patti, E.W. Christen, and T.R. Cavagnaro. 2011. Review: Winery wastewater quality and treatment options in Australia. Aust. J. Grape Wine Res. 17:111-122.

Mosse, K.P.M., J. Lee, B.T. Leachman, S.J. Parikh, T.R. Cavagnaro, A.F. Patti, and K.L. Steenwerth. 2013a. Irrigation of an established vineyard with winery cleaning agent solution (simulated winery wastewater): Vine growth, berry quality, and soil chemistry. Agr. Water Manage. 123:93-102.

Mosse, K.P.M., T.V. Verheyen, A.J. Cruickshank, A.F. Patti, and T.R. Cavagnaro. 2013b. Soluble organic components of winery wastewater and implications for reuse. Agr. Water Manage. 120:5-10.

NOAA. 2013. Climate of 2013 - April U.S. Palmer Drought Indices. In Current Palmer Drought Indices. R. Heim (ed.). National Climatic Data Center.

North Coast Stream Flow Coalition. 2009. North Coast Stream Flow Campaign. http://www.ourstreamsflow.org/NCSFC_website/Home. html.

Oliver, P., R. Rodriguez, and S. Udaquiola. 2008. Water use optimization in batch process industries. Part 1: Design of the water network. J. Clean. Prod. 16:1275-1286.

Qian, J.G., and K. Mopper. 1996. Automated high performance, hightemperature combustion total organic carbon analyzer. Anal. Chem. 68:3090-3097. 
Quirk, J.P., and R.K. Schofield. 1955. The effect of electrolyte concentration on soil permeability. J. Soil Sci. 6:163-178.

Quirk, J.P., C Pereira, and T.W. Tanton. 1986. Soil permeability in pelation to sodicity and salinity. Phil. Trans. R. Soc. Lond. A 316:297-317.

Rengasamy, P. 2002. Transient salinity and subsoil constraints to dryland farming in Australian sodic soils: An overview. Aust. J. Exp. Agric. 42:351-361.

Shepherd, H.L., M.E. Grismer, and G. Tchobanoglous. 2001. Treatment of high-strength winery wastewater using a subsurface-flow constructed wetland. Water. Environ. Res. 73:394-403.

Sims, C.A., and J.R. Morris. 1984. Effects of pH, sulfur dioxide, storage time, and temperature on the color and stability of red Muscadine grape wine. Am. J. Enol. Vitic. 35:35-39.

Smyth, M., and J. Russell. 2009. 'From graft to bottle'-Analysis of energy use in viticulture and wine production and the potential for solar renewable technologies. Renew. Sust. Energ. Rev. 13:1985-1993.

Spencer, R.G.M., G.R. Aiken, K.P. Wickland, R.G. Striegl, and P.J. Hernes. 2008. Seasonal and spatial variability in dissolved organic matter quantity and composition from the Yukon River basin, Alaska. Global Biogeochem. Cy. 22:GB4002.

Storm, D.R. 2001. Winery Utilities: Planning, Design and Operation. Springer, New York.

SWRCB. 2014. State Water Resources Control Board. Rule AB1739. Policy for maintaining instream flows in Northern California coastal streams. In C.E.P. Agency (ed.). California Environmental Protection Agency, Sacramento, CA. http:/www.waterboards.ca.gov/waterrights/ water_issues/programs/instream_flows/docs/adopted_policy.pdf

U.S. EPA. 1979. Biochemical Oxygen Demand (5 Days, $\left.20^{\circ} \mathrm{C}\right)$, Method 405.1.

U.S. EPA. 2004. Guidelines for Water Reuse. EPA 625/R-04/108. Office of Research and Development, National Risk Management Research Laboratory. Cincinnati, OH. http://nepis.epa.gov/Adobe/ PDF/30006MKD.pdf.

Vlyssides, A.G., E.M. Barampouti, and S. Mai. 2005. Wastewater characteristics from Greek wineries and distilleries. Water Sci. Technol. 51:53-60.

Walsdorff, A., M. van Kraayenburg, and C.A. Barnardt. 2005. A multisite approach towards integrating environmental management in the wine production industry. Water Sci. Technol. 51:61-69.

Weber, E., S.R. Grattan, B.R. Hanson, G.A. Vivaldi, R.D. Meyer, T.L. Prichard, and L.J. Schwankl. 2014. Recycled water causes no salinity or toxicity issues in Napa vineyards. Calif. Agr. 68:59-67.

Weishaar, J.L., G.R. Aiken, B.A. Bergamaschi, M.S. Fram, R. Fujii, and K. Mopper. 2003. Evaluation of specific ultraviolet absorbance as an indicator of the chemical composition and reactivity of dissolved organic carbon. Environ. Sci. Technol. 37:4702-4708. 